\section{Royal Charter for Physicists}

SIR,--There was considerable discussion in Nature $\mathbf{2 2 0}$, $952 ; 1968)$ of the Charter proposals when these were presented to the members of the Institute of Physics and the Physical Society in November. The provisions, involving the abolition of the Fellowship of the Physical Society, have continued to arouse strong opposition on the part of a responsible body of Fellows. Despite this opposition the Charter petition has now been presented to the Privy Council for approval.

Those who find the Charter unacceptable should now consider seriously the formation of the British Physical society. This is being actively discussed at Imperial College by a small committee, who would like to hear from those interested.

\section{Yours faithfully,}

\section{BlaCKMAN}

Department of Physics,

Imperial College of

Science and Technology,

London SW7.

\section{Appointments}

THE following appointments have been made by the Medical Research Council to its Research Boards and Grants Committees: Professor R. Doll (until recently of the MRC's Clinical Research Centre and the MRC Statistical Unit), Professor W. S. Peart (St Mary's Hospital Medical School, London) and Professor A. C. Turnbull (Welsh National School of Medicine, Cardiff) to the Clinical Research Board; Dr J. O'H. Tobin (Withington Hospital, Manchester) and Professor A. C. Turnbull to the Clinical Research Board Grants Committee 1; Professor J. G. Robson (Royal Postgraduate Medical School, London) to the Clinical Research Board Grants Committee 2; Professor T. W. Goodwin (University of Liverpool), Dr J. H. Humphrey (National Institute for Medical Research) and Professor R. E. O. Williams (St Mary's Hospital Medical School, London) to the Biological Research Board; Professor R. A. Gregory (University of Liverpool), already a member of this board, as chairman in succession to Professor J. L. Gowans; Dr D. B. Hope (University of Oxford) to the Biological Research Board Grants Committee 2; Professor T. W. Goodwin, already a member of this committee, as chairman in succession to Professor A. S. V. Burgen; and Dr H. Jolly (Charing Cross Hospital, London) and Dr G. Pringle (Liverpool School of Tropical Medicine) to the Tropical Medicine Research Board.

\section{Announcements}

THE British Association for Crystal Growth was formed on June 25, 1969, to encourage the scientific and technological discussion of the theory and practice of crystal growth and the appraisal of erystals. The first committee consists of Professor A. D. McQuillan (chairman), Dr W. Bardsley, Mr J. C. Brice (treasurer), Dr D. Elwell (secretary), Professor F. C. Frank, Professor C. H. L. Goodman, Mr B. A. Joyce, Dr J. B. Mullin, Mrs B. M. Wanklyn and Dr E. A. D. White. Anyone interested in joining the association should contact Dr D. Elwell, Department of Physies, Portsmouth Polytechnic, Park Road, Portsmouth POI 2DZ.

The Gold Medal of the Entomological Society of Canada has been awarded to Dr K. E. F. Watt, University of California at Davis, in recognition of his contributions to insect ecology.

The Perkin Gentenary Trust invites applications for the Perkin Centenary Scholarships and Perkin Travel Grants for $1970-1$. The scholarships are offered to candidates employed in the United Kingdom in an industrial firm or other institution concerned with the manufacture or the application of colouring matters, for study at a university or technical college. The travel grants are available to teachers concerned with the study of any aspect of the manufacture or the application of colouring matters at universities, technical colleges or other institutions in the United Kingdom, who wish to gain experience at similar institutions in Europe. Further details may be obtained from The Secretary, The Perkin Centenary Trust, c/o The Chemical Society, Burlington House, London WIV OBN.

IN connexion with the announcement (Nature, 223, 1395; 1969) of the appointment of Dr H. W. Springer as Secretary-General of the Association of Commonwealth Universities, we have been asked to point out that the present Secretary-General, Dr J. F. Foster, does not retire until the end of September 1970.

Erratum. In the article "Donsities of the Terrestrial Planets" by W. H. McCrea (Nature, 224, 28; 1969), the abscissa-axis in Fig. 1 should be labelled "Mass $\left(10^{27} \mathrm{~g}\right)$ ", not "Mass $\left(10^{2} / \mathrm{g}\right)$ ".

Erratum. In the article "Ribosomal Subunits and MS2 Phage RNA-directed Protein Synthesis" by Grubman and Nakada (Nature, 223, 1242; 1969), the first sentence of the twelfth paragraph (page 1245) should read: "The requirement of protein synthesis for ribosomal subunit dissociation was shown as follows". The first sentence of the eighteenth paragraph (page 1246) should read: "Requirement of the initiation of protein synthesis for the ribosomal subunit exchange ....".

\section{International Meetings}

March 31-April 3, Yield, Deformation and Fracture of Polymers, Cambridge (Meetings Officer, The Institute of Physics and the Physical Society, 47 Belgrave Square, London $\mathrm{SW1}$ ).

April 1-3, X-ray Analysis-Past, Present and Future, London (Meetings Officer, The Institute of Physics and the Physical Society, 47 Belgrave Square, London SW1).

April 1-4, Thermodynamics, Cardiff (Meetings Officer, The Institute of Physics and the Physical Society, 47 Belgrave Square, London SW1).

April 2-3, Applications of High Voltage Electron Microscopy, Harwell (Meetings Officer, 'The Institute of Physics and the Physical Society, 47 Belgrave Square, London SW1).

April 6-8, Joint Meeting of the Association for High Speed Photography and the Shock Tube Liaison Group, Liverpool (Dr L. Davies, Aerodynamies Division, National Physical Laboratory, Teddington, Middlesex, UK).

April 6-8, Chemistry and Mineralogy of Meteorites and Extraterrestrial Matter, London (Mr P. Wilkinson, Department of Geology, University of Sheffield, Mappin Street, St George's Square, Sheffield, S1 3JD).

April 6-11, Bio-Engineering 1970, Oxford (Conference Secretary, Biological Engineering Society, Mr J. Gasking, Department of Pharmacology, St Bartholomew's Hospital Medical School, Charterhouse Square, London EC1).

April 7-10, Experimental Stress Analysis and Its Influence on Design, Cambridge (Mr R. J. Millson, The Institution of Mechanical Engineers, 1 Birdeage Walk, Westminster, London SW1).

April 7-10, Thermophysical Properties of Solids at High Temperatures, Risley (Meetings Officer, The Institute of Physics and the Physical Society, 47 Belgrave Square, London SW1). 